
ОСТРЫЙ ФЛЕГМОНОЗНЫЙ ДИВЕРТИКУЛИТ ТОЩЕЙ КИШКИ КАК ПРИЧИНА РАЗЛИТОГО ГНОЙНОГО ПЕРИТОНИТА

\author{
ДешукA.H. (dziashuk@mail.ru),ЦилиндзьИ.T. (surgery@grsmu.by), \\ АвдееваE.Ю. (elizoveto4k@mail.ru) \\ УО «Гродненский государственный медицинский университет», Гродно, Беларусь
}

Введение. Дивертикул тонкой кишки - патологическое мешковидное выпячивание, которое сообщается непосредственно через отверстие с полостью органа. При задержке остатков пищи в дивертикулах формируются каловые камни, провоцирующие бактериальные инфекции и на их фоне - дивертикулит. Воспаление ограничивается одним дивертикулом или может перейти на близлежащие ткани и органы, следствием чего может стать межкитечный абсиесс, перитонит либо забрюшинная флегмона.

Цель: улучшить результаты лечения пациентов с острым дивертикулитом тонкого кишечника.

Материал и методы. В статье представлены материалы собственного клинического наблюдения хирургического лечения пациента с острым флегмонозным дивертикулитом тощей кишки. Пащиенту в 2016 г. выполнена лапаротомия с резекцией участка тощей кишки вместе в деструктивным дивертикулом.

Bыводы. Острый флегмонозный дивертикулит тощей кишки - редкая хирургическая патология, диагностируемая чаще всего во время оперативного лечения по экстренным показаниям.

Ключевые слова: острый флегмонозный дивертикулит, тощзая кишка, перитонит, лапаротомия.

Дивертикул тонкой кишки - патологическое мешковидное выпячивание, которое сообщается непосредственно через отверстие с полостью органа $[1,4,5]$. Данная патология тонкого кишечника относится к редким заболеваниям желудочно-кишечного тракта и составляет 1-2\% от всех заболеваний данной системы органов, встречается в основном у пожилых людей и детей [2, 4]. Как правило, у пациентов обнаруживается множественное образование дивертикулов по ходу тонкой кишки, именуемое термином “дивертикулез”. Мешковидные дефекты различаются своей формой и размерами, а также природой происхождения $[1,5]$.

Большинство врачей относят дивертикулы к случайным находкам при рентгенологических исследованиях, во время операции или вскрытий, в то время, когда они являются причиной заболевания. Так, по данным отечественных и зарубежных авторов, дивертикулы тонкой кишки встречаются до $22 \%$ всех вскрытий. По рентгенологическим данным, дивертикулы встречаются в 0,2-0,3\% всех рентгенологических исследований желудочно-кишечного тракта $[3,4]$.

На сегодняшний день в клинической практике данная патология диагностируется крайне редко, что связано прежде всего с недостаточной информированностью практических врачей о ней, несовершенством методов диагностики, особенно при осложненных дивертикулах двенадцатиперстной кишки $[2,4,5]$.

До настоящего времени не установлены причины образования дивертикулов. Считается, что дивертикулез развивается в результате нарушений перистальтики, кишечной дискинезии или повышения сегментарного внутрипросветного давления, кроме того, данная патология может быть врожденной $[1,3,5]$.

При задержке остатков пищи в дивертикулах формируются каловые камни, провоцирующие бактериальные инфекции и на их фоне - дивертикулит. Воспаление ограничивается одним ди- вертикулом или может перейти на близлежащие ткани и органы, следствием чего может стать межкишечный абсцесс, перитонит либо забрюшинная флегмона $[1,3]$.

Ниже приводим наше наблюдение. Пациент К., 54 лет (история болезни № 8144), был доставлен в приемное отделение ГУЗ «Городская клиническая больница № 4 г. Гродно» машиной скорой медицинской помощи 29.08.2016 в 18.50 из ГУЗ «Городская поликлиника №1 г. Гродно» с диагнозом «Острый аппендицит? Острый панкреатит?» При поступлении пациент предъявлял жалобы на острые постоянные, ноющие боли в эпигастральной области, иррадиирующие в спину, тошноту, рвоту желудочным содержимым с примесью желчи, сухость во рту, общую слабость, потливость, повышение температуры тела до $37-37,8^{\circ} \mathrm{C}$. При сборе анамнеза было установлено, что заболел он около 3-х суток назад, когда начали появляться вышеописанные симптомы с нарастанием их интенсивности проявления; общее состояние не улучшалось, самочувствие ухудшалось, в результате чего пациент обратился в поликлинику по месту жительства.

При объективном исследовании в приемном покое: состояние средней степени тяжести, сознание ясное. Телосложение правильное. В легких дыхание везикулярное, хрипов нет. Тоны сердца ритмичные, ясные. Пульс 78 ударов в минуту, ритм правильный. АД $=130 / 80$ мм рт. ст. Язык сухой, обложен белым налетом. Живот не вздут, симметричен, участвует в акте дыхания равномерно, при пальпации мягкий, болезненный в эпигастральной области. Аускультативно ослабление кишечных шумов. Перкуторно определяется тимпанический звук в эпигастральной области и в области левого подреберья. Симптомы Черемских-Кушнеренко, Ситковского, Ровзинга, Образцова, Бартомье-Мехельсона, Затлера, Мэйо-Робсона, Раздольского, Воскресенского, Щеткина-Блюмберга отрицательные. При пальцевом исследовании прямой кишки 
патологических изменений не выявлено. Температура тела $37,4^{\circ} \mathrm{C}$. Выполнено ультразвуковое исследование органов брюшной полости и забрюшинного пространства. Печень: размеры увеличены, КВР правой доли 168 мм, контуры ровные, эхогенность повышена, структура неоднородная, очаговых образований нет. Желчный пузырь нормальных размеров, конкрементов не обнаружено. Общий желчный проток 5 мм, внутрипеченочные желчные протоки не расширены. Поджелудочная железа: головка - 28 мм, тело 17 мм, хвост - 26 мм, контур ровный, структура неоднородная, эхогенность повышена, Вирсунгов проток - норма. Селезенка и почки без особенностей. В малом тазу и брюшной полости свободная жидкость не визуализируется. Произведена фиброгастродуоденоскопия, заключение: эритематозная гастропатия. На обзорной рентгенограмме брюшной полости единичные чаши Клойбера в верхнем этаже брюшной полости; свободного газа под куполами диафрагмы не выявлено. В общем анализе крови: лейкоциты $13,3 \times 10^{9} /$ л, эритроциты $4,68 \times 10^{12} /$ л, гемоглобин 143 г/л. В биохимическом анализе крови: мочевина 6,2 ммоль/л, креатинин 107 мкмоль/л, билирубин общий 42,2 ммоль/л, билирубин прямой 22,2 ммоль/л, амилаза 35,4 Ед/л, калий 4,68 ммоль/л, натрий 150 ммоль/л, хлориды 95 ммоль/л. Пациент был осмотрен терапевтом, выставлен диагноз: ИБС: диффузный кардиосклероз, атеросклероз аорты, коронарных и мозговых артерий. Пациент госпитализирован в хирургическое отделение № 1 с диагнозом: «Хронический рецидивирующий панкреатит в стадии обострения». Назначено консервативное лечение: инфузионная терапия, анальгин, папаверин, димедрол, спазматон, диклофенак, омепразол.

Однако на фоне консервативной терапии состояние пациента не улучшалось, около 21.10 29.08.2016 начали беспокоить боли внизу живота, по правому боковому каналу, при пальпации напряжение мышц в левой боковой и околопупочной областях, надлобковой, правой и левой подвздошных областях, ограниченное участие мышц передней брюшной стенки в акте дыхания, положительные симптомы Раздольского, Воскресенского, Щеткина-Блюмберга в вышеописанных областях передней брюшной стенки, что было связано с прорывом абсцесса в брюшную полость. Выставлен диагноз: «Острый аппендицит? Острый панкреатит? Перитонит». С целью исключения данных заболеваний пациенту предложена диагностическая лапароскопия, выполненная 29.08.2016 в 22.30. При ревизии: по ходу обоих боковых каналов жидкий гной. Срединная лапаротомия. В других областях около 200 мл густого гноя - осушен, париетальная и висцеральная брюшина этих областей гиперемирована и отечна, тонкая кишка немного раздута, перистальтирует. Установлено, что, начиная с 30 см от связки Трейтца, на протяжении около 40 см расположены множественные дивертикулы тощей кишки разного размера, один из которых бурый, отечный, обложен фибрином (флегмонозный), находится в кармане брюшины левого синуса с образованием абсцесса. До этого участка тощая кишка раздута, стенка ее перерастянута, а далее - спавшаяся (рисунок).

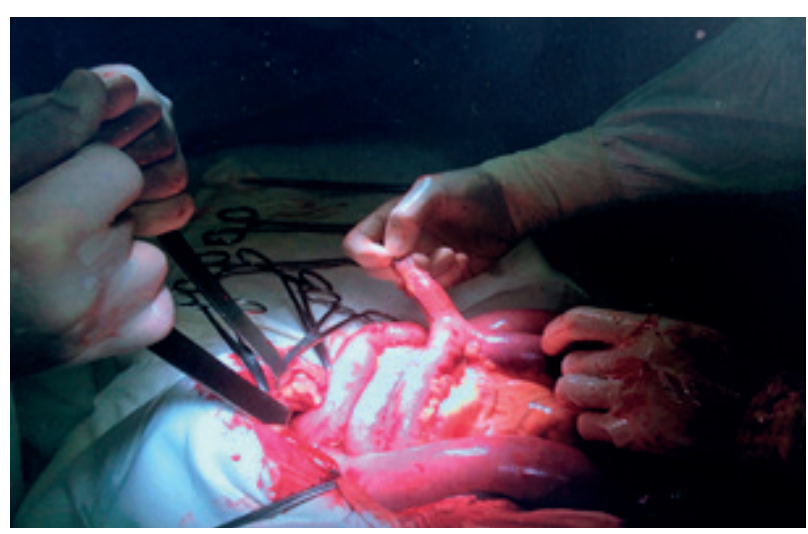

Рисунок. - Острое воспаление дивертикула тощей кишки с деструкцией его стенки

Диагноз: «Острый флегмонозный дивертикулит тощей кишки. Разлитой гнойный перитонит». Участок тощей кишки, несущий дивертикулы, в том числе флегмонозный, резецирован с применением аппаратного шва и перитонизирован. Сформирован еюноилеоанастомоз «бок в бок». Окно в брыжейке ушито. Брюшная полость промыта раствором фурацилина до чистой жидкости (7 литров), дренирована по правому и левому боковым каналам. Контроль гемостаза. Послойные швы на рану. Йодонат. Асептические повязки. Патоморфологическое исследование участка резецированной кишки: тонкая кишка 50 см, синюшно-красного цвета на всем протяжении, диаметром от 2,5 до 3 см. В двух участках на расстоянии 7 см от первого края 2 мешковидных выпячивания диаметром 1,5 и 2 см, соответственно. Результат патологогистологического исследования: хронический энтерит, дивертикулы тонкой кишки с серозно-гнойным воспалением в стенках.

В течение трех суток после операции пациент находился в отделении реанимации, после чего был переведен в хирургическое отделение. Получал лечение: инфузионная терапия, фрагмин, прозерин, ранитидин, фуросемид, метронидазол, кеторолак, ципрофлоксацин, цефазолин, цефтриаксон. Рана зажила первичным натяжением, швы сняты на 10-е сутки. На 11-е сутки после операции пациент выписан домой в удовлетворительном состоянии.

\section{Выводы}

1. Острый флегмонозный дивертикулит тощей кишки - редкая патология, клинически граничащая с другими острыми хирургическими заболеваниями органов брюшной полости.

2. Диагностика данного острого воспалительного заболевания достаточно затруднительна и часто постановка правильного диагноза возможна лишь при выполнении экстренного оперативного вмешательства. 


\section{Литература}

1. Мяконький, Р. В. Случай дивертикулярной болезни тонкой кишки, осложнившейся перфорацией дивертикула с образованием межкишечного абсцесса и развитием острой кишечной непроходимости / Р. В. Мяконький, К. О. Каплунов // Волгоградский научно-медицинский журнал. - 2016. - № 4. - С. 55-59.

2. Федоров, И. В. Роль лапароскопии в лечении острого дивертикулита / И. В. Федоров // Главный врач Юга России. - 2013. - № 2 (33). - С. 44-48.

3. Щербаков, П. Л. Успехи эндоскопии в диагностике и лечении болезней тонкой кишки / П. Л. Щербаков // Терапевтический архив. - 2013. - Т. 85, № 2. C. 93-95.

4. Butler, J. S. Perforated jejunal diverticula: a case report / J. S. Butler, C. G. Collins, G. P. McEntee // Journal of Medical Case Reports. - 2010. - Vol. 172, № 4. - P. 172.

5. Successful double balloon enteroscopy treatment for bleeding jejunal diverticulum: a case report and review of the literature / C. W. Yang [et al.] // Journal of Laparoendoscopic \& Advanced Surgical Techniques. 2009. - Vol. 19, № 5. - P. 637-640.

\section{References}

1. Myakonky RV, Kaplunov KO. Sluchaj divertikuljarnoj bolezni tonkoj kishki, oslozhnivshejsja perforaciej divertikula s obrazovaniem mezhkishechnogo abscessa i razvitiem ostroj kishechnoj neprohodimosti [A case of diverticular disease of the small intestine complicated by perforation of the diverticulum, interintestinal abscess and acute intestinal obstruction]. Volgogradskij nauchnomedicinskij zhurnal [Volgograd Journal of Medical Research]. 2016;4:55-59. (Russian).

2. 2 Fedorov IV. Rol laparoskopii $\mathrm{v}$ lechenii ostrogo divertikulita [The role of laparoscopy in the treatment of acute diverticulitis]. Glavnyj vrach Juga Rossii [Chief Physician of the South of Russia]. 2013;2(33):44-48. (Russian).

3. Shcherbakov PL. Uspehi jendoskopii v diagnostike $\mathrm{i}$ lechenii boleznej tonkoj kishki [Progress in endoscopybased diagnosis of small bowel diseases]. Terapevticheskiy arkhiv [Therapeutic archive]. 2013;85(2):93-95. (Russian).

4. Butler JS, Collins CG, McEntee GP. Perforated jejunal diverticula: a case report. Journal of Medical Case Reports. 2010;172(4):172.

5. Yang CW, Chen YY, Yen HH, Soon MS. Successful double balloon enteroscopy treatment for bleeding jejunal diverticulum: a case report and review of the literature. Journal of Laparoendoscopic \& Advanced Surgical Techniques. 2009;19(5):637-640.

\title{
ACUTE FLEGMONOUS DIVERTICULITIS OF JEJUNUM AS A CAUSE OF DIFFUSE PURULENT PERITONITIS
}

\author{
Dziashuk A. N., Tsylindz I. T., Avdeeva E. Y.
}

Educational Institution «Grodno State Medical University», Grodno, Belarus

Background. Diverticulum of the small intestine is a pathological saccate protrusion, which communicates directly through the opening with the cavity of the organ. With the delay of food remains in the diverticula, stools are formed, which provoke bacterial infections and against their background diverticulitis. Inflammation is limited to one diverticulum or can go to nearby tissues and organs, resulting in an interstitial abscess, peritonitis, or retroperitoneal phlegmon.

Aim. To improve the results of treatment of patients with acute small intestine's diverticulitis.

Material and methods. The article presents materials of own clinical observation of surgical treatment of a patient with acute phlegmonous diverticulitis in the jejunum. In 2016, a patient underwent laparotomy with resection of the jejunum together with a destructive diverticulum.

Conclusions. Acute phlegmonous diverticulitis of the jejunum is a rare surgical pathology, diagnosed most often during surgical treatment for emergency indications.

Keywords: acute phlegmonous diverticulitis, jejunum, peritonitis, laparotomy.

Поступила: 01.11.2017

Отрецензирована: 07.12.2017 